\title{
On new and interesting records of spiders from northern Pakistan and India (Aranei)
}

\section{Новые и интересные находки пауков в северном Пакистане и северной Индии (Aranei)}

\author{
Yuri M. Marusik1, Francesco Ballarin ${ }^{2,3}$, Mikhail M. Omelko ${ }^{4,5}$, \\ Seppo Koponen ${ }^{6}$ \\ Ю.М. Марусик ${ }^{1}$, Ф. Бамларинн,3, М.М. Омемько ${ }^{4,5}$, С. Копонен
}

\footnotetext{
${ }^{1}$ Institute for Biological Problems of the North of the Russian Academy of Sciences, Portovaya Str. 18, 685000 Magadan, Russia. E-mail: yurmar@mail.ru

${ }^{2}$ Institute of Zoology, Chinese Academy of Sciences, 1 Beichen West Road, Chaoyang District, Beijing 100101, P.R. China. E-mail: ballarin.francesco@gmail.com

${ }^{3}$ Museo Civico di Storia Naturale di Verona, Lungadige Porta Vittoria, 9 - 37129, Verona, Italy.

${ }^{4}$ Far Eastern Federal University, Sukhanova, 8, Vladivostok 690950 Russia. Email: omelkom@gmail.com

${ }^{5}$ Gornotaezhnaya Station FEB RAS, Gornotaezhnoe Vil., Ussuriyski Dist., Primorski Krai 692533 Russia.

${ }^{6}$ Zoological Museum, University of Turku, FI-20014, Turku, Finland. E-mail: sepkopo@utu.fi

${ }^{1}$ Институт биологических проблем Севера ДВО РАН, Портовая 18, Магадан 685000.

${ }^{4}$ Дальневосточный Федеральный университет, Суханова 8, Владивосток, 690950, Россия.

${ }^{5}$ Горнотаёжная станция им. В.Л. Комарова ДВО РАН, с. Горнотаёжное, Уссурийский район, Приморский край 692533, Россия.
}

KEY WORDS: Aranei, Gnaphosidae, Lycosidae, Theridiidae, India, Pakistan, China, Afghanistan, Himalaya. КЛЮЧЕВЫЕ СЛОВА: Aranei, Gnaphosidae, Lycosidae, Theridiidae, Индия, Пакистан, Китай, Гималаи.

ABSTRACT. The present work shows new faunistic and taxonomic data on nine species from Northern Pakistan and India belonging to the families Gnaphosidae, Lycosidae and Theridiidae. Berlandina afghana Denis, 1958, Parasyrisca alai Ovtsharenko, Platnick et Marusik, 1995, Pardosa algoides Schenkel, 1963, and Leptodrassex memorialis (Spassky, 1940) are reported for the first time in the Pakistanian fauna; Pardosa haupti Song, 1995, is new for India and Gnaphosa dege Ovtsharenko, Platnick et Song, 1992 and Enoplognatha diodonta Zhu et Zhang, 1992, are new for both the countries. New distribution data are provided for Micaria lenzi Bösenberg, 1899 and M. pulcherrima Caporiacco, 1935. Berlandina afghana Denis, 1958 is removed from the synonymy of $B$. plumalis (O. Pickard-Cambridge, 1872). An unusual structure was found and illustrated in epigyne of Leptodrassex memorialis. All nine species are illustrated and comments on their taxonomy and distribution are provided.

РЕЗЮМЕ. В работе приводятся новые фаунистические и таксономические данные по 9 видам пауков из северных регионов Пакистана и Индии относящихся к Gnaphosidae, Lycosidae и Theridiidae. Berlandina afghana Denis, 1958, Parasyrisca alai Ovtsharenko, Platnick et Marusik, 1995, Pardosa algoides Schenkel, 1963 и Leptodrassex memorialis (Spas- sky, 1940) впервые отмечены в Пакистане, Pardosa haupti Song, 1995 впервые отмечается для Индии. Gnaphosa dege Ovtsharenko, Platnick et Song, 1992 и Enoplognatha diodonta Zhu et Zhang, 1992 впервые найдены в Пакистане и Индии. Приведены новые данные по распространению Micaria lenzi Bösenberg, 1899 и M. pulcherrima Caporiacco, 1935. Berlandina afghana Denis, 1958 ревалидизирована и выведенаиз синонимов $B$. plumalis (O. Pickard-Cambridge, 1872). Обнаружена и проиллюстрирована необычная структура в эпигине Leptodrassex memorialis. Для всех 9 видов приводятся рисунки и комментарии по таксономии и распространению.

\section{Introduction}

The pioneer work about spiders of northern India (=NW Himalaya) was published by O.P.-Cambridge [1885]. He studied the material collected during the second Yarkand Mission and reported from there 131 species, 109 of which were described as a new to science. The route of expedition runs across modern Pakistan, India, Tajikistan and Xizang (Tibet, now province of China). The second paper dealing with spiders of this region was published by Caporiacco [1935]. Most of the spiders treated in his work were collected by him during the Italian Mission to Karakoram in 


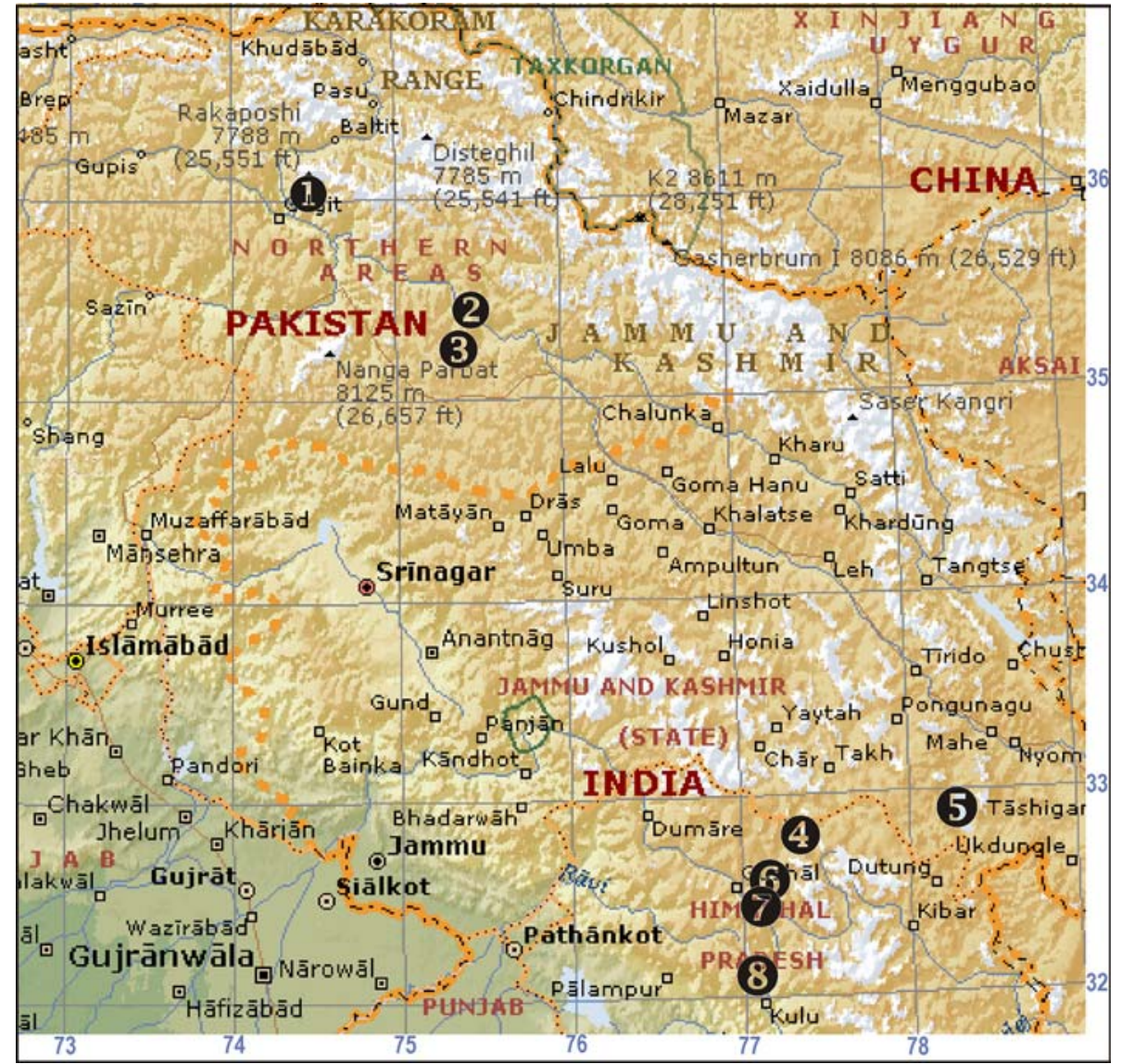

Map 1. Collecting localities in Pakistan and India: $1-\mathrm{Ba}-$ grot and Kergat valleys; 2 Skardu District (no precise locality); 3 - Deosai Plateau; 4 - Tso Moriri; 5 - Surajtal Lake; 5 - Keylong Town; 7 Sissu Village; 8 - Patlikuhl Town.

Карта 1. Места сборов в Пакистане и Индии: 1 - долины Bagrot и Kergat; 2 район Skardu District (без точной привязки); 3 - плато Deosai; 4 - Tso Moriri; 5 озеро Surajtal; 5 - г. Keylong; 7 - дер. Sissu; 8 - пос. Patlikuhl.
1929. He reported 172 species of Arachnids, 163 of which are spiders, and 93 species and subspecies were described as new to science. Simultaneously, another paper dealing with spiders from Karakoram was published by Reimoser [1935]. He reported 20 species and 18 more specimens not identified to species level. Two species were described as new to science.

More recently Denis [1958] and Roewer [1960a,b, 1961, 1962a,b] studied the fauna of the adjacent Afghanistan country and described several dozen new species. Since then, no special papers devoted to spiders of this region were published. Afterwards several other species have been mentioned in taxonomic revisions or descriptions of the older material [Prószyński, Zochowska, 1981; Wesołowska, 1986; Marusik, 1993; Danilov, 1997; Ovtchinnikov, Inayatullah, 2005; Ovtchinnikov, 2006, Ovtchinnikov et al., 2008, 2009; Logunov et al., 2011, Marusik, Ballarin, 2011a,b; etc.].

Recently, new material was collected by Italian and Czech zoologists, and the senior author of this paper, in the northern Pakistan and India. We had an opportunity to examine these specimens. Among them we were able to identify only a few species which were either known from the original descriptions, or recently revised but not yet recorded in this area. Main goal of this paper is to provide the names of new species and genera records of the families Lycosidae, Gnaphosidae and Theridiidae to Pakistan and/or India.

\section{Material and methods}

Microphotographs were made with an Olympus Camedia E-520 camera attached to an Olympus SZX16 stereomicroscope at the Zoological Museum, University of Turku, Finland. Digital images were composed using "CombineZP" image stacking software and edited with Corel Photo Paint X4 and Corel Paint Shop Pro Photo X2. Photographs were taken using paraffin based dishes with different sized holes to keep the samples in the required position. Epigynes were macerated in $\mathrm{KOH}$.

The specimens studied in this work are preserved in the collections of the Museo Civico di Storia Naturale di Verona, Italy (MSNV) and the Zoological Museum of Moscow State University, Russia (ZMMU). All measurements are in millimetres.

\section{Survey of species}

\section{GNAPHOSIDAE}

Berlandina afghana Denis, 1958, reinstated Figs 1, 3-6.

B. a. Denis, 1958: 92, f. 14 ()

B. a. spinitarsis Denis, 1958: 92, f. $15(+)$.

MATERIAL EXAMINED. PAKISTAN: $1+$ (MSNV) GilgitBaltistan, Skardu Distr., 2300 m, 1.07.1976 (G. Osella). 
Figs 1-2. Females of Berlandina afghana (1) and Leptodrassex memorialis (2).

Рис. 1-2. Самки Berlandina afghana (1) и Leptodrassex memorialis (2).
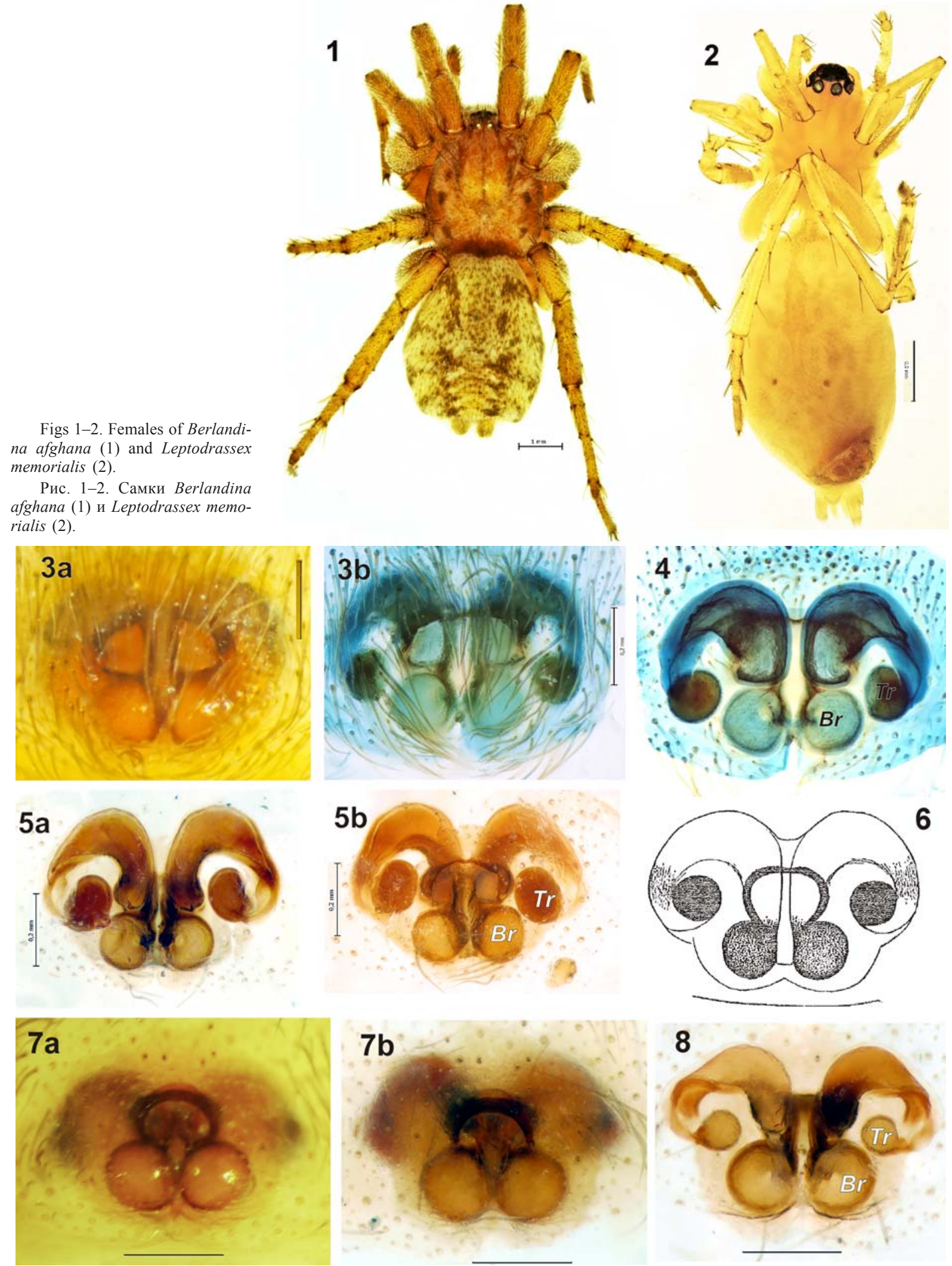

Figs 3-8. Epigyne of Berlandina afghana (3-6) and B. plumalis (7-8, from Israel): 3, 5b, 6-7 - epigyne, ventral; 4, 5a, 8 - epigyne, dorsal. 3-5 - specimens from Pakistan. 6 - after Denis [1958]. Abbreviations: $B r$ - basal receptacle, $T r$ - terminal receptacle.

Рис. 3-8. Эпигина Berlandina afghana (3-6) и B. plumalis (7-8, из Израиля): 3, 5b, 6-7 - эпигина, снизу; 4, 5a, 8 - эпигина, сверху. 3-5 - из Пакистана. 6 - по Denis [1958]. Сокращения: $B r$ - базальная рецептакула, $T r$ - терминальная рецептакула. 

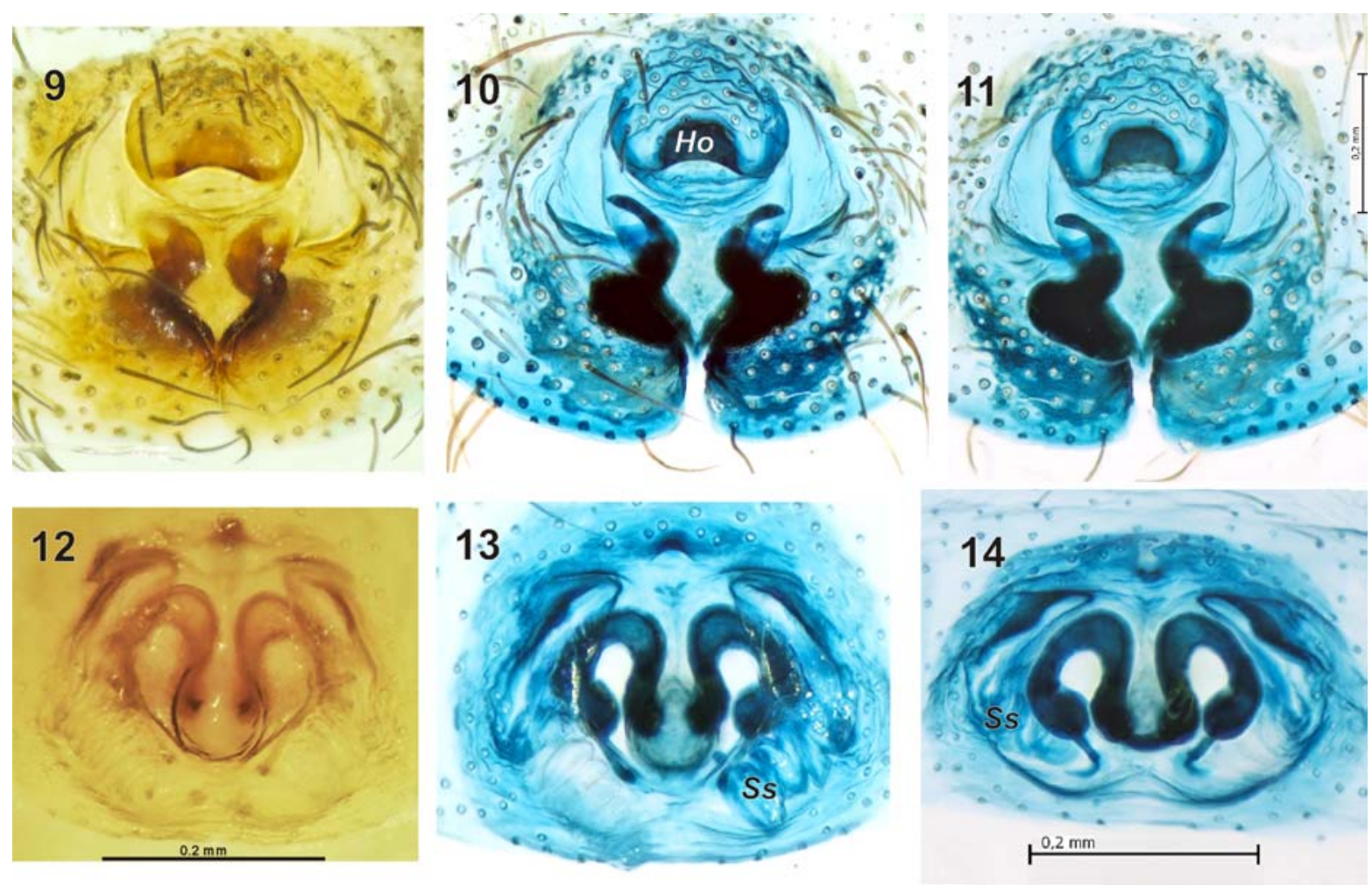

Figs 9-14. Epigyne of Gnaphosa dege (9-11) and Leptodrassex memorialis (12-14): 9-10, 12-13 — ventral; 11, 14 - dorsal. Abbreviations: Ho - hood of scape, $S s$ - spiraled structure.

Рис. 9-14. Эпигина Gnaphosa dege (9-11) и Leptodrassex memorialis (12-14): 9-10, 12-13 - снизу; 11, 14 - сверху. Сокращения: Ho - карман скапуса; $S s$ - спиральная структура.

COMMENTS. Denis [1958] described a new species B. afghana with two subspecies (afghana and spinitarsis), from Afghanistan. Later, B. afghana was synonymized by Levy [1995] with B. plumalis (O. Pickard-Cambridge, 1872). Comparison of specimens from Pakistan (Figs 3-5), and these from Israel (type locality of $B$. plumalis) revealed that they are not conspecific. Specimens from Israel (Figs 7-8) have basal receptacle $(B r)$ much larger than terminal $(T r)$, while in the Pakistanian specimen, and in the specimen drawn by Denis [1958; cf. Fig. 6], the receptacles are subequal in size.

Gnaphosa dege Ovtsharenko, Platnick et Song, 1992 Figs 9-11.

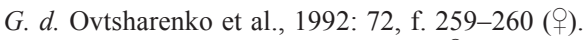

G. $d$.: Song et al., 1999: 448, f. 261B (+).

G. $d$ : : Song et al., 2004: 95, f. 52A-B (+).

MATERIAL EXAMINED. KYRGYZSTAN: 6 우 (ZMMU), Dzhetymbel Mts, Suyok Pass, 3800 m, 10-13.06.1997 (D. Obydov). PAKISTAN: 1 ; 2 juv. (MSNV) Gilgit-Baltistan, Skardu Distr., Doesai Plateau, from 3900 to 4200 m, 27.06.2008 (L. Latella). INDIA: 5 우 3 juv. (ZMMU), [IN-15] Himachal Pradesh, Surajtal Lake, 32 $46^{\prime} \mathrm{N} 77^{\circ} 24^{\prime} \mathrm{E}, 4800 \mathrm{~m}, 14.06 .1999$ (Yu.M. Marusik).

COMMENTS. Although there are three taxonomic entries to this species, it is actually known only by the type series: seven females from Kyrgyzstan and eastern Sichuan, China. The new records from India and Pakistan extend the known range southward and indicate that it probably occurs in Tajikistan and Xizang (Tibet, China) as well. It is likely that $G$. namulinensis $\mathrm{Hu}, 2001$, described and known from Xizang, might be a junior synonym of $G$. dege since $G$. namulinensis has the same shape and size of epigyne and vulva. Samples from India, collected in only one location, show females of different sizes (total length from 6.5 to 9.5, and carapaces from 3.1 to 4.0 long). There are slightly different shapes and widths of the epigyne septum and fovea (0.36-0.43), but the vulva appearance is equal in all the specimens. The illustration provided in the original description does not show the pocket (hood, $\mathrm{Ho}$ ) of the scape.

\section{Leptodrassex memorialis (Spassky, 1940)}

Figs 2, 12-14.

Leptodrassus m. Spassky, 1940: 355, pl. 7, f. 2-5 ( $0^{7}+$ ). Leptodrassus nemoralis: Eskov, Marusik, 1995: 77, f. 45-47 $\left(0^{7}+\right)^{2}$.

L. m.: Kovblyuk, Nadolny, 2010: 192, f. 20-39 (o'o).

For the complete list of references see Platnick [2014].

MATERIAL EXAMINED. PAKISTAN: 1 (MSNV) GilgitBaltistan, Skardu Distr., 2300 m, 1.07.1976 (G. Osella).

COMMENTS. While making photographs of the macerated epigyne we noticed the presence of unusual spiraled structure $(S s)$ inside the closed chamber (Figs 13-14). The endogyne has a complicated structure with several folds. 

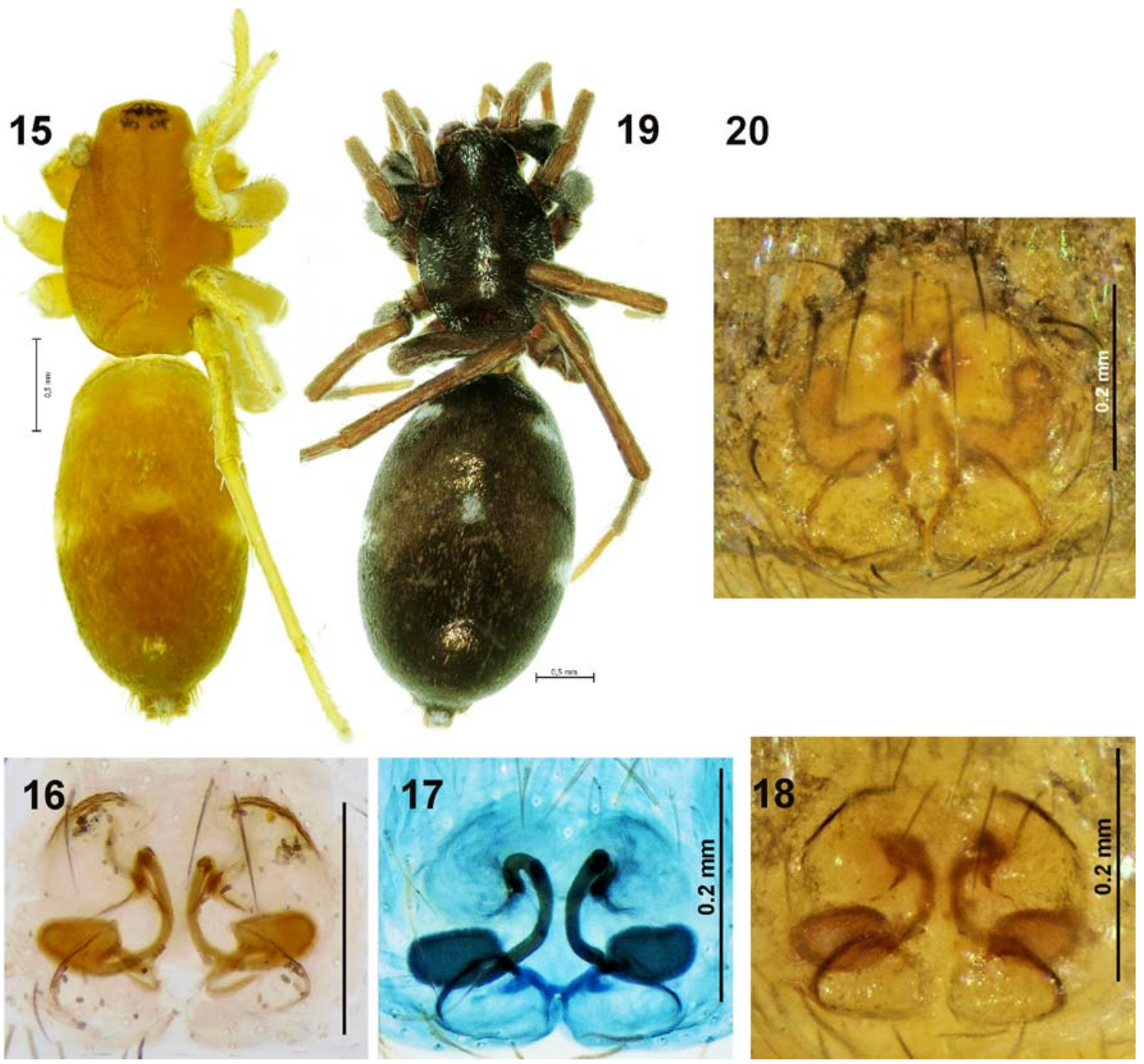

Figs 15-20. Females of Micaria lenzi (15-18) and M. pulcherrima (19-20): 15, 19 - habitus; 17-18, 20 - epigyne, ventral; 16 epigyne, dorsal.

Рис. 15-20.Самки Micaria lenzi (15-18) и M. pulcherrima (19-20): 15, 19 - внешний вид; 17-18, 20 - эпигина, снизу; 16 эпигина, сверху.

Previously, this species was known from southern Russia, Crimea, northeastern Kazakhstan, and Mongolia [Platnick, 2014]. The present record extends the known range of this species about 6 degrees to the south.

\section{Micaria lenzi Bösenberg, 1899}

Figs 15-18.

M. l.: Wunderlich, 1979: 277, f. 6, 29a-d, 51a-c (O'P).

M. l.: Mikhailov, Marusik, 1995: 102, f. 31-32, 37 (О'i).

M. l.: Song et al., 1999: 452, f. 264D, O (O'P).

For the complete list of references, see Platnick [2014].

MATERIAL EXAMINED. PAKISTAN: 1 ( (MSNV) GilgitBaltistan, Skardu Distr., 2300 m, 1.07.1976 (G. Osella).

COMMENTS. This species has a Transpalaearctic range and is known from Europe to Chukotka (northeastern Asia). It was previously recorded from this region as $M$. mutilata Caporiacco, 1935 (a junior synonym of M. lenzi) by Caporiacco [1935].
Micaria pulcherrima Caporiacco, 1935

Figs 19-20.

M. p. Caporiacco, 1935: 221, pl. 6, f. 8 (O'P).

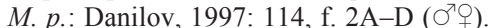

M. p.: Song et al., 1999: 452, f. 264E, P (O'P).

M. p.: Song et al., 2004: 179, f. 106A-E (O'o).

For the whole list of taxonomic references, see Platnick [2014].

MATERIAL EXAMINED. INDIA: 1 \% 1 juv. (ZMMU) [IN16], Himachal Pradesh, Keylong City environs, $32^{\circ} 34^{\prime} \mathrm{N}, 77^{\circ} 01^{\prime} \mathrm{E}$, 3100-3400 m, 12-17.06.1999 (Yu.M. Marusik); 3 O $^{7} 0^{7}$ (ZMMU) [IN-14], Sissu Village, $32^{\circ} 28^{\prime} \mathrm{N}, 77^{\circ} 07^{\prime} \mathrm{E}, 3150 \mathrm{~m}$, pitfall traps, 917.06.1999 (Yu.M. Marusik); $50^{7} 0^{7} 5$ OQ⿻ 2 juv. (ZMMU), Sissu Village, $32^{\circ} 28.1^{\prime} \mathrm{N} 77^{\circ} 07.9^{\prime} \mathrm{E}, 3150-3500 \mathrm{~m}$, 8-10.06.1999 (Yu.M. $^{\circ}$ Marusik).

COMMENTS. This species has a rather wide range, and was known from northern Pakistan and India (Jammu and Kashmir regions) to Hebei in China [Song et al., 2004], north to Tuva and Buryatia [Marusik et al., 2000] in Russia. The new record extends the known range about $400 \mathrm{~km}$ to the south. 

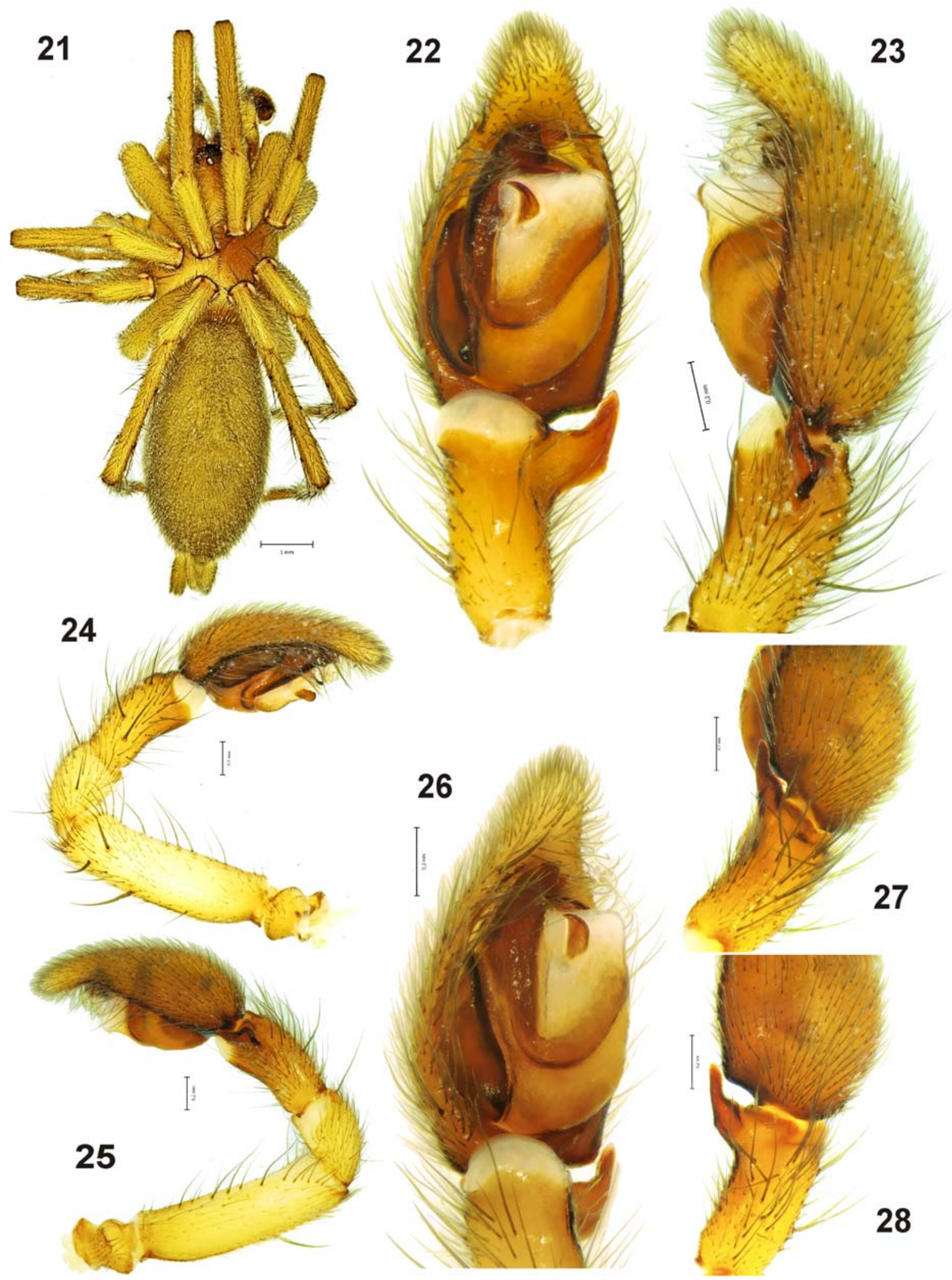

Figs 21-28. Male of Parasyrisca alai: 21 - habitus; 22 - palp, ventral; 23,25 - palp, retrolateral; 24 - palp, prolateral; 26 palp, prolateral-ventral; 27-28 - palp, retrolateral-dorsal.

Рис. 21-28. Самец Parasyrisca alai: 21 - внешний вид; 22 — пальпа, снизу; 23, 25 — пальпа, ретролатерально; 24 — пальпа, пролатерально; 26 - пальпа, пролатерально-снизу; 27-28 - пальпа, ретролатерально-сверху. 

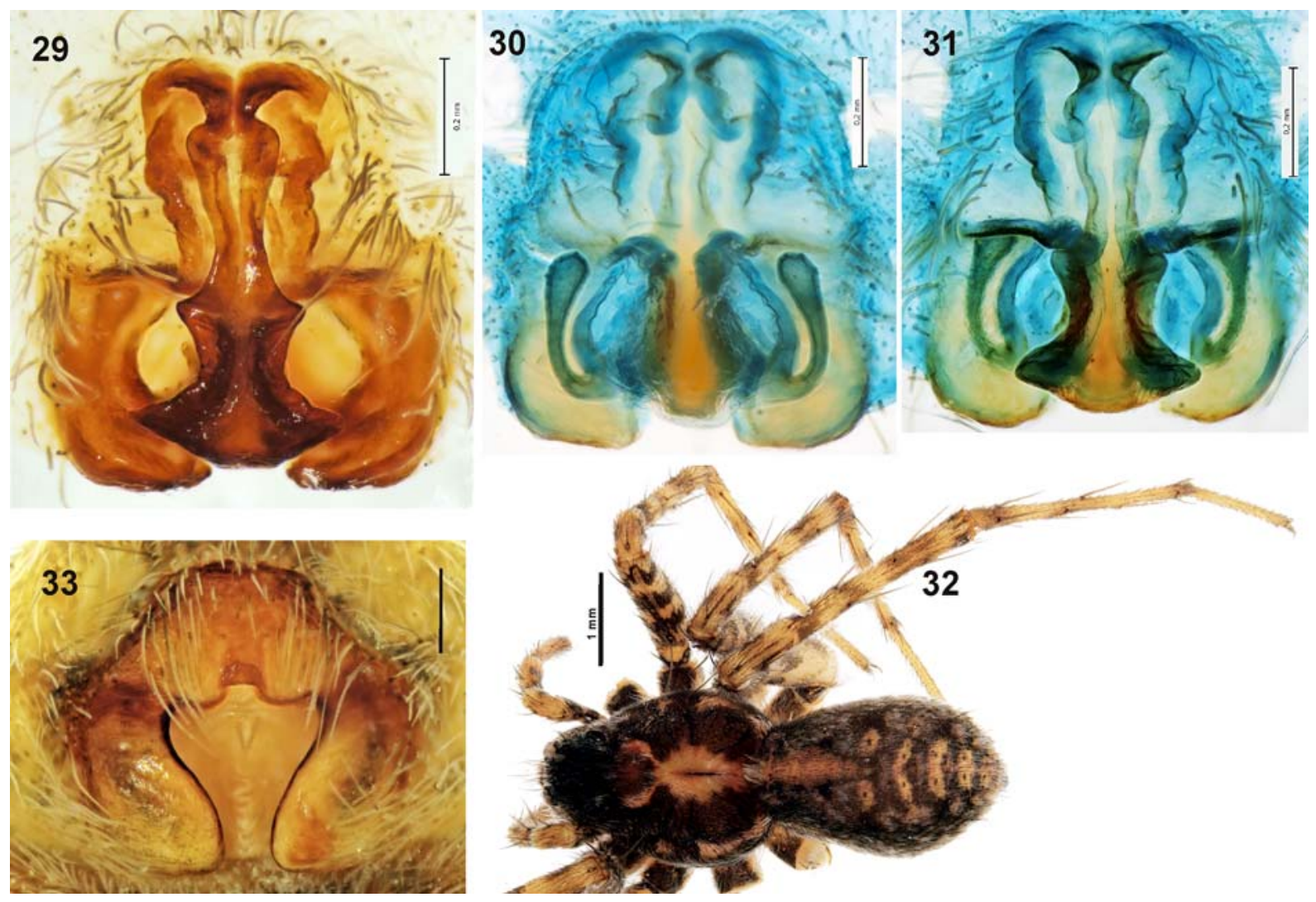

Figs 29-33. Females of Pardosa algoides (29-32) and P. haupti (33): 29, 31, 33 - epigyne, ventral; 30 - epigyne, dorsal; 32 habitus.

Рис. 29-33. Самки Pardosa algoides (29-32) и P. haupti (33): 29, 31, 33 - эпигина, снизу; 30 - эпигина, сверху; 32 внешний вид. 1995

Parasyrisca alai Ovtsharenko, Platnick et Marusik,

Figs 21-28.

P. a. Ovtsharenko et al., 1995: 30, f. 100-102 (O').

MATERIAL EXAMINED. PAKISTAN: $10^{7}$ (MSNV) GilgitBaltistan, Skardu Distr., Doesai Plateau, from 3900 to $4200 \mathrm{~m}$, 28.06.2008 (L. Latella).

COMMENTS. To date, this species was known from a single entry, and only from the male holotype from Kyrgyzstan. The new find in Pakistan extends the known range of about $500 \mathrm{~km}$ (or $4.5^{\circ}$ ) to the south. Both the species and genus are new to Pakistan.

\section{LYCOSIDAE}

Pardosa algoides Schenkel, 1963

Figs 29-32.

P. uncata Schenkel, 1963: 365, f. 211a-b (O', preoccupied by Banks [1894]).

P. a. Schenkel, 1963: 367, f. 212-213 (+)

P. ladakhensis Tikader, 1977: 144, f. 1-3 (+).

P. a.: Song et al., 1999: 329, f. 192K, R (O'P). [2014].

For the complete list of taxonomic references, see Platnick

MATERIAL EXAMINED. INDIA: 1 ( Kashmir, Rupshu, Tso Moriri - Peldo (ca. $32.870^{\circ} \mathrm{N}, 78.337^{\circ} \mathrm{E}$ ),

4540 m, 24.08.1999 (L. Klimeš); 1 † (ZMMU), Jammu \& Kashmir, Rupshu, Kyigar Tso and above Tso Moriri, 4750-5800 m, 1823.08.1999 (L. Klimeš). PAKISTAN: 2 우 (MSNV), Northern Areas, Gilgit Distr., Bagrot Valley, 18.06.2008 (L. Latella).

COMMENTS. This species has a wide range and was known from Ladakh (Jammu \& Kashmir, India) to Qinghai and south to Sichuan (China) and Bangladesh. Although it was known from the adjacent India, this species has not been reported from Pakistan. The new record extends the know range of about $150 \mathrm{~km}$ to the West.

Pardosa haupti Song, 1995

Fig. 33.

P. h. Song in Song, Haupt, 1995: 2, f. 2A-D (O'P).

P. h.: Song et al., 1999: 331, f. 194L-M. 195B (O'+ $)$.

P. h.: Hu, 2001: 211, f. 110.1-4 (O'P).

MATERIAL EXAMINED. INDIA: 2 우 (ZMMU), Jammu \& Kashmir, Rupshu, Kyagar Tso and above Tso Moriri $\left(33.110^{\circ} \mathrm{N}\right.$ 78.310 E), 4750-5800 m, 18-23.08.1999 (L. Klimeš).

COMMENTS. So far, this species was known from three provinces in China: Gansu, Qinghai and Xinjiang. The new record extends the known range far to the south-west. The presence of this species in the Jammu and Kashmir Province suggests that it may also occur in adjacent Tibet and Pakistan. 

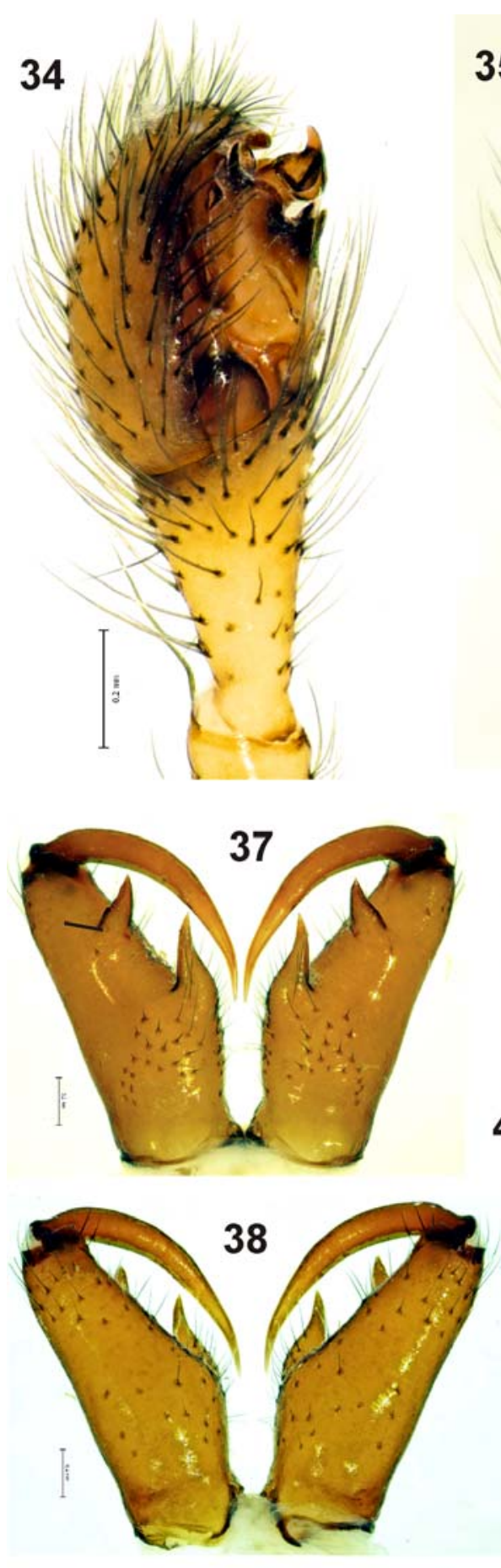

\section{5}
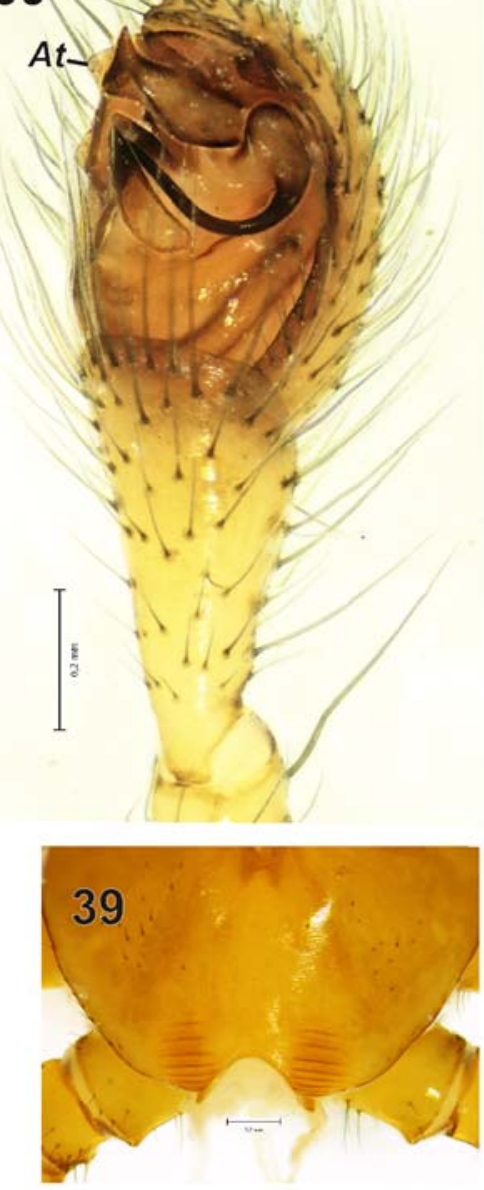

41

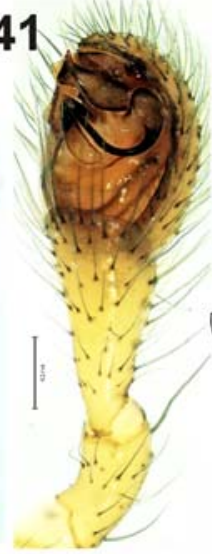

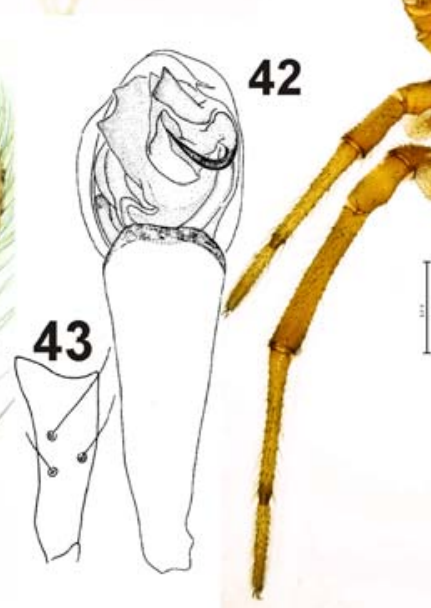
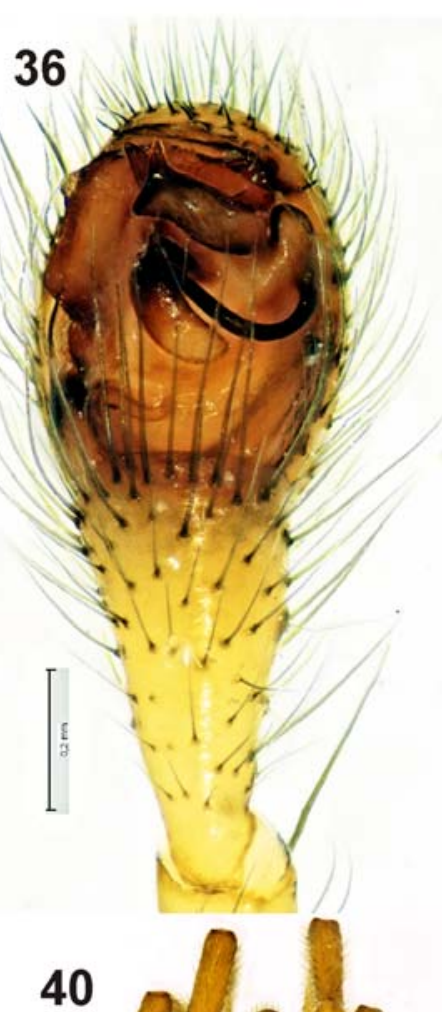

40
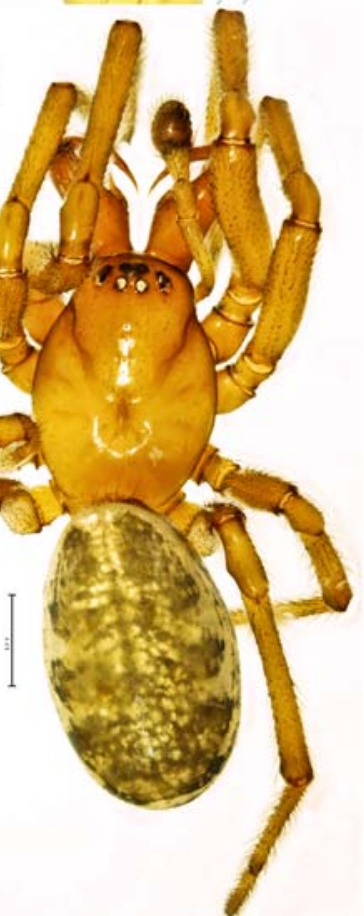

Figs 34-43. Male of Enoplognatha diodonta: 34-36 - male palp, prolateral, ventral and retrolateral; 37-38 - chelicerae, anterior and posterior; 39 - back side of carapace showing stridulatory ridges; 40 - habitus; $41-42$ - palp, ventral; 43 - palpal tibia, retrolateral. 42-43 - after Zhu [1998]. Abbreviation: At - apical tooth of the median apophysis.

Рис. 34-43. Самец Enoplognatha diodonta: 34-36 - пальпа самца, пролатерально, снизу и ретролатерально; 37-38 хелицеры, спереди и сзади; 39 - задняя часть карапакса, показаны стридуляционные борозды; 40 - внешний вид; 41-42 пальпа, снизу; 43 - голень пальпы, ретролатерально. 42-43 - по Zhu [1998]. Сокращение: $A t$ — апикальный зубчик медиального отростка. 


\section{THERIDIIDAE}

\section{Enoplognatha diodonta Zhu et Zhang, 1992} Figs 34-43.

E. d. Zhu, Zhang, 1992: 26, f. 6A-G (?).

E. $d$ : Zhu, 1998: 318, f. 214A-G (ठㅇ).

E. $d$.: Song et al., 1999: 118, f. $58 \mathrm{~K}-\mathrm{N}\left(\sigma^{7}+\right)$.

MATERIAL EXAMINED. PAKISTAN: $1 \sigma^{7}$ (MSNV) Northern Areas, Gilgit Distr., Bagrot Valley, 2160 m, 25.10-2.11.2008 pitfall trap (L. Latella \& R. Ahmed); $3 \sigma^{\top} \sigma^{\top}$ (MSNV) Kergat Valley, 26.10-3.11.2008, pitfall trap (L. Latella \& R. Ahmed) INDIA, Himachal Pradesh, 4 q+ (ZMMU), Patlikuhl Town, $32^{\circ} 07.4^{\prime} \mathrm{N}, 7^{\circ} 08.8^{\prime} \mathrm{E}$, ca. $1200 \mathrm{~m}, 28-29.05 .1999$ (Yu.M. Marusik); 1 ㅇ (ZMMU), same locality, 17-23.06.1999 (Yu.M. Marusik).

COMMENTS. Until now this species was known only from China and exclusively in three south-eastern provinces: Guangxi, Zhejiang and Hunan [Song et al., 1999]. These records are new to Pakistan and India and extend the known range of about $8^{\circ}$ to the north and $28^{\circ}$ to the west. Males from northern Pakistan have the same shape of bulbus as in specimen illustrated by Zhu \& Zhang [1992] with an apical tooth (At) on the median apophysis, unusual for the genus Enoplognatha. All other species belonging to this genus show a basal tooth only. Males from Pakistan differ from the figures provided by Chinese authors by having a shorter palpal tibia. Zhu [1998] illustrates two different kinds of palpal tibia, one very long (Fig. 42) and one of normal size (Fig. 43), exactly the same size as in Pakistanian specimens. It is likely that on Fig. 42 tibia is drawn together with the patella.

ACKNOWLEDGEMENTS. We are particularly grateful to Leonardo Latella who gave us the opportunity to study the material from Karakoram preserved in the Museo Civico di Storia Naturale di Verona, Italy. Many thanks to Alexander V. Gromov for identifications of $q$ of $E$. diodonta and to late L. Klimeš for providing us the material from Jammu \& Kashmir. English of the final draft was checked by Robin Leech (Edmonton, Canada). This study was supported in part by the Russian Foundation for Basic Research (grant $\checkmark$ 12-04-01548), Far Eastern Federal University, and by the Finnish CIMO fellowship.

\section{References}

Banks N. 1897. Descriptions of new spiders // Canadian Entomologist. Vol.29. P.193-197.

Caporiacco L. 1935. Aracnidi dell'Himalaia e del Karakoram, raccolti dalla Missione italiana al Karakoram (1929-VII) // Memorie della Società Entomologica Italiana. No.13. P.113-263.

Danilov S.N. 1997. New data on the spider genus Micaria Westring, 1851 in Asia (Aranei Gnaphosidae) // Arthropoda Selecta. Vol.5. No.3. P.113-116

Denis J. 1958. Araignées (Araneidea) de l’Afghanistan. I. // Videnskabelige Meddelelser Dansk Naturhistorisk Forening. No.120. P.81-120.

Eskov K.Y., Marusik Y.M. 1995. On the spiders from Saur Mt Range, eastern Kazakhstan (Arachnida: Araneae) // Beiträge zur Araneologie. Bd.4. P.55-94.

Hu J.L. 2001. Spiders in Qinghai-Tibet Plateau of China. Henan: Henan Science and Technology Publishing House. 658 p.

Kovblyuk M.M., Nadolny A.A. 2010. Cryptodrassus hungaricus and Leptodrassex memorialis from Crimea (Aranei: Gnaphosidae) // Arthropoda Selecta. Vol.19. No.3. P.189-197.
Levy G. 1995. Revision of the spider subfamily Gnaphosinae in Israel (Araneae: Gnaphosidae) // The Journal of Natural History. Vol.29. P.919-981.

Logunov D.V., Ballarin F., Marusik Y.M. 2011. New faunistic records of the jumping and crab spiders of Karakoram (Aranei: Philodromidae, Salticidae and Thomisidae) // Arthropoda Selecta. Vol.20. No.3. P.233-240.

Marusik Y.M. 1993. Re-description of spiders of the families Heteropodidae and Thomisidae (Aranei), described by O. P.-Cambridge from the material of the second Yarkand mission // Entomological Review. Vol.72. P.456-468.

Marusik Y.M., Logunov D.V., Koponen S. 2000. Spiders of Tuva, south Siberia. Magadan: Institute for Biological Problems of the North. 253 p.

Marusik Y.M., Ballarin F. 2011a. A new species of Draconarius Ovtchinnikov, 1999 (Araneae, Amaurobioidea, Coelotinae) from northern Pakistan // Zootaxa. No.2739. P.27-32.

Marusik Y.M., Ballarin F. 2011b. Redescription of the Himalaian Pardosa flavisterna Caporiacco, 1935 (Aranei: Lycosidae) with notes of the Pardosa nebulosa species-group // Proceedings of the Zoological Institute Russian Academy of Sciences. No.315. P.63-69.

Mikhailov K.G., Marusik Y.M. 1995. [Spiders of the North-East of the USSR. Families Clubionidae, Zoridae, Liocranidae and Gnaphosidae (genus Micaria) (Arachnida, Aranei)] // Entomologicheskie issledovaniya na Severo-Vostoke SSSR. Vladivostok. No.2. P.90-113 [in Russian]

Ovtchinnikov S.V. 2006. New genus and species of spiders of the subfamily Zodariinae (Araneae, Zodariidae) from Pakistan // Vestnik Zoologii. Vol.40. P.77-79.

Ovtchinnikov S.V., Ahmad B., Gurko V.O. 2009. Parazodarion, a new genus of the spider family Zodariidae (Araneae) from Asia // Vestnik Zoologii. Vol.43. P.471-474.

Ovtchinnikov S.V., Ahmad B., Inayatullah M. 2008. Description of a new spider species of the genus Gnaphosa (Araneae, Gnaphosidae) from Pakistan // Vestnik Zoologii. Vol.42. P.81-83.

Ovtchinnikov S.V., Inayatullah M. 2005. Two new spider species of the genus Draconarius (Araneae, Amaurobiidae, Coelotinae) from Pakistan // Vestnik Zoologii. Vol.39. P.85-88.

Pickard-Cambridge O. 1885. Scientific results of the second Yarkand mission. Araneida. Calcutta. 15 p.

Platnick N.I. 2014. The World Spider Catalog, Version 15 American Museum of Natural History, online at http://research. amnh.org/entomology/spiders/catalog/index.html (Accessed 28 August, 2014).

Prószyński J., Zochowska K. 1981. Redescriptions of the O. P.Cambridge Salticidae (Araneae) types from Yarkand, China // Polskie Pismo Entomologiczne. Vol.51. P.13-35.

Reimoser E. 1935. Araneida// Wissenschaftliche Ergebnisse der niederländischen Expeditionen in den Karakorum. Zoologie. Leipzig. P.169-176.

Roewer C.F. 1960a. Solifugen und Opilioniden - Araneae Orthognathae, Haplogynae und Entelegynae (Contribution à l'étude de la faune d'Afghanistan 23) // Göteborgs Kongliga Vetenskapsoch Vitterhets-Samhäles Handlingar. Vol.8. No.7. S.1-53.

Roewer C.F. 1960b. Lycosidae aus Afghanistan (Araneae) // Acta Universitatis lundensis (N.F.). Vol.56. No.17. S.1-34.

Roewer C.F. 1961. Araneae Dionycha aus Afghanistan I // Acta Universitatis lundensis (N.F.). Vol.58. No.3. S.1-33.

Roewer C.F. 1962a. Araneae Dionycha aus Afghanistan II // Acta Universitatis lundensis (N.F.), Vol.58. No.4. S.1-34.

Roewer C.F. 1962b. Araneae Trionycha II und Cribellatae aus Afghanistan // Acta Universitatis lundensis (N.F.). Vol.58. No.7. S.1-15

Schenkel E. 1963. Ostasiatische Spinnen aus dem Muséum d'Histoire naturelle de Paris // Memoirs du Museum National d'Histoire Naturelle (France). Nouvelle Serie. Serie A. Zoologie. No.25. P.1-481.

Song D.X.. Haupt J. 1995. Wolf spiders of the genus Pardosa (Araneae: Lycosidae) from Karakorum and Hoh Xil, China // Acta arachnologica sinica. No.4. P.1-10.

Song D.X., Zhu M.S., Chen J. 1999. The Spiders of China. Shijiazhuang: Hebei Science Technolology Publishing House. 640 p. 
Song D.X., Zhu M.S., Zhang F. 2004. Fauna Sinica: Invertebrata Vol. 39: Arachnida: Araneae: Gnaphosidae. Beijing: Science Press. 362 p.

Spassky S. 1940. Araneae palaearcticae novae. V // Folia zoologica hydrobiologica. Vol.10. No.2. P.353-364.

Tikader B.K. 1977. Description of two new species of wolf-spider (Family: Lycosidae) from Ladakh, India // Journal of the Bombay Natural History Society. No.74. P.144-146.

Wesołowska W. 1986. A revision of the genus Heliophanus C. L. Koch, 1833 (Aranei: Salticidae) // Annales Zoologici, Warszawa. No.40. P.1-254
Wunderlich J. 1979. Revision der europäischen Arten der Gattung Micaria Westring 1851, mit Anmerkungen zu den übrigen paläarktischen Arten (Arachnida: Araneida: Gnaphosidae). Beiträge zur Zoologie. Bd.25. S.233-341.

Zhu M.S., Zhang Y.Q. 1992. Notes of some species of Theridiidae in Guangxi (Arachnida: Araneae) // Journal of Guangxi Agricultural and Biological Science. Vol.11. No.1. P.20-29.

Zhu M.S. 1998. Fauna Sinica: Arachnida: Araneae: Theridiidae. Beijing: Science Press. 436 p.

Responsible editor Kirill Mikhailov 